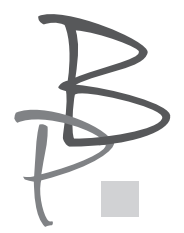

BIBLIOTEKARZ PODLASKI

4/2021 (LIII)

https://doi.org/10.36770/bp.649

ISSN 1640-7806 (print) ISSN 2544-8900 (online)

www.bibliotekarzpodlaski.pl

\author{
Adam Sawicki* \\ Uniwersytet Pedagogiczny w Krakowie, Polska / \\ / Pedagogical University of Krakow, Poland \\ ORCID: 0000-0003-0651-2691
}

\title{
Wobec tajemnicy i skandalu zła - teodycea Karola Ludwika Konińskiego
}

In the face of mystery and the scandal of evil the theodicy by Karol Ludwik Koniński

Abstract: The article presents religious and philosophical views of journalist and writer Karol Ludwik Koniński (1891-1943), which he included in his intimate journal, written mostly during the war and the occupation period. He intertwines his observations of daily dramatic events with reflections on the metaphysical and ethical status of evil present in the world. Koniński was inspired in his theodicy, trying to reconcile the image of merciful God with the severity of evil present in the world, the views of Gnostics and Origen. He took the view that God was not fully omnipotent, and emphasized that on a cosmic scale the process of overcoming multiform evil by God, who is Love, is constantly taking place. Koniński's theodicy therefore constitutes religious evolutionism. He combined Gnostic sensitivity to the presence and severity of evil with the belief in the ultimate, full apocatastasis. Koniński's reflection does not accept some of the dogmas of Roman Catholicism, it

* Adam Sawicki - prof. dr hab., kierownik Katedry Ontologii i Metafizyki na Uniwersytecie Pedagogicznym w Krakowie, autor m.in. dysertacji: Rosyjska immortologia. Śmierć i nieśmiertelność w poglądach myślicieli XVIII-XX w. (Białystok-Kraków 2016). 
also includes a critique of the views of St. Augustine and scholastic theology. The author of the article puts forward a thesis that Koniński, due to his in-depth analysis of the subject of evil and his sensitivity to the dramatic dimension of human and non-human existence, can be attributed to a particular current of the philosophy of the heart, in Pascal's understanding of this concept.

Keywords: Koniński, theodicy, Gnosticism, Origen, evil, omnipotence, philosophy of the heart, mystery.

Zwieńczeniem ludzkiej refleksji jest metafizyka, ponieważ stawia ona pytania najwyższej wagi, i jeżeli szukamy pełnej powagi w świecie czczej gadaniny i przyjmowania różnych intelektualnych póz - to powinniśmy jej szukać w metafizyce. Metafizyka docieka zagadnienia ostatecznych racji bytu, napina do krańcowych możliwości ludzkie zdolności poznawcze. Wychodzi poza krąg czysto ludzkich spraw, ponieważ ujmuje je w możliwie najszerszej pozaludzkiej perspektywie. Pytania o istnienie i atrybuty Boga, nieskończoność, wieczność, wolność, przestrzeń, czas, byt, nicość odnoszą się do samych fundamentów rzeczywistości. Podobnie jest z próbą określenia relacji pomiędzy Bogiem (przy założeniu Jego istnienia) a światem znajdującym się w takim stanie, jaki w swoim codziennym bytowaniu odbieramy, poznajemy i przeżywamy.

A jak wygląda relacja człowieka do świata? Z jednej strony jest to relacja czerpania z jego obfitości, co służy podtrzymaniu i rozwijaniu życia ludzkiego, z drugiej zaś, to relacja ciągłego zagrożenia pochodzącego od żywiołowych aspektów światowej rzeczywistości. Czyli świat jako niosący dobro, ale i zarazem smagający człowieka różnymi, przewidywalnymi i nieprzewidywalnymi odmianami zła. W ten sposób dochodzimy do tematyki teodycei, rozumianej jako próba pogodzenia wyobrażenia Stwórcy jako istoty nieskończenie dobrej i obdarzającej dobrem, a zarazem wszechmocnej oraz wszechwiedzącej przy jaskrawej obecności zła w doświadczanym przez ludzi świecie. Temat ten przyciąga i pochłania uwagę kolejnych pokoleń myślicieli - filozofów i teologów.

Każdy człowiek doświadcza, czy też doświadczył w swoim życiu jakiegoś zła. Ale są ludzie, którzy nie ograniczają się do samego doznawania zła 
i znoszenia jego ciosów. Próbują zrozumieć, skąd zło w świecie się wzięło, jaki jest sens jego obecności, jak się ma do dobra. Taką właśnie szczególną wrażliwość i dociekliwość można dostrzec w filozoficznej twórczości Karola Ludwika Konińskiego (1891-1943), publicysty i pisarza. Nie był on profesjonalnym, uniwersyteckim filozofem. Jego filozofowanie było przede wszystkim owocem własnych doświadczeń życiowych i wyostrzonego zmysłu obserwacji zdarzeń i procesów, które miały miejsce w otaczającym go środowisku i w świecie poza nim. Od czasu I wojny światowej zmagał się z poważną chorobą, gruźlicą kręgosłupa, która stopniowo ograniczała jego możliwości ruchowe. U schyłku swojego życia, w okresie hitlerowskiej okupacji, w podkrakowskiej Rudawie zapisywał swój intymny dziennik, który przynależy do piśmiennictwa nurtu medytacyjnego, będąc szczególnym świadectwem moralnej wrażliwości i metafizycznej przenikliwości. Stanowi on ponadto wyraz głębokiej religijnej wiary, która rodziła się i trwała w bólach wątpliwości, jak też zastrzeżeń.

Filozofowie, w większości chyba przypadków, dążą do możliwie najbardziej zobiektywizowanego sposobu wyrażania swoich przemyśleń, nie pogrążania rozumowych rozważań w świat subiektywnych przeżyć i odczuć. Koniński łączy w swoich zapiskach te porządki. Mamy więc surową rzeczywistość okupacyjną i jej codzienne dramaty, o których autor w swoim dzienniku pisze, będąc nimi do głębi poruszony. Można powiedzieć, że zapiski Konińskiego, pisane nie według jakiegoś z góry założonego planu, zawierają w sobie przeplot zapisu z obserwacji trudnej materii codziennego życia, i to obserwacji dokonywanej przez człowieka cierpiącego fizycznie, i myśli filozoficznej, która stara się, przebijając się poprzez tę materię, odnaleźć drogę do Boga, odkryć przestrzeń religijnej wiary.

Części dziennika Konińskiego zostały wydane po wojnie: Nox atra (1961), Ex labyrintho (1962), Uwagi 1940-1942 (1987)1. Kazimierz Wyka, który utrzymywał z Konińskim kontakty w ostatnich latach jego życia, w ten oto sposób charakteryzuje Nox atra i Ex labyrintho:

1 Obszerne opracowanie na temat poglądów Konińskiego: K. Ludwicki, Bóg-zło-modlitwa. Wokół ,, Uwag 1940-1942” Karola Ludwika Konińskiego, Kraków 2016, także: B. Mamoń, Karol Ludwik Koniński, Kraków 1969. 
Tak powstały dwa bardzo prawdziwe i nieposiadające analogii w naszym piśmiennictwie tomy. Gdyby przez porównanie określić ich wygląd, jest to coś pomiędzy Dziennikiem Amiela a Dziennikiem Hebbla, bliżej znacznie Hebbla na skutek tego, że w pamiętniku Konińskiego nie ma śladu egotyzmu, że panuje w nim podobnie surowa atmosfera myślowa, co u Hebbla. Notaty tych obydwu tomów z uporczywą natrętnością powracają wciąż do jednego problemu: poszukiwanie Boga, moźliwość istnienia Boga w świecie rzeczywistym, świecie walki i zła. [...] Szukanie Boga miało u niego specjalny wygląd. Posiadał nadczułą wrażliwość moralną, odrzucał w sposób bezwzględny przekonanie, by świat rzeczywisty, przyroda, tzw. celowość wszechświata dowodziły istnienia pierwiastka transcendentalnego².

Intelektualny pamiętnik Konińskiego przypomina też, zarówno pod względem formy zapisu, jak i wiodącej tematyki filozoficzno-teologicznej, Myśli Błażeja Pascala, z tą jednak różnicą, że Pascal nie odwołuje się w nich do szczegółowych zdarzeń z życia codziennego. Ale temperatura uczuciowa zapisu jest w obydwu przypadkach podobna. Wyostrzone spojrzenie na rzeczywistość ludzką i pozaludzką, na dramaty w niej rozgrywające się i żarliwe poszukiwanie śladów obecności Boga łączy obu myślicieli. Podobnie jak Pascal, Koniński stoi po stronie „filozofii serca”, ale nie oznacza to rezygnacji z prób rozumowego ogarniania rzeczywistości. Rozum nie dostępuje jakiejś formy ostatecznego jego potępienia. Pozostaje chłodnym świadkiem wysiłków zapanowania nad pękniętą z powodu obecności zła rzeczywistością przez moralną świadomość wyposażoną w czuły narząd sumienia, która daje jedyną szansę usensownienia życia.

Koniński rejestruje dramaty ludzkich istnień, jak i też, co należy podkreślić, dramaty w świecie zwierzęcym, i odnosi to do pozycji Boga w stosunku do świata. W wątpliwość zostaje podany atrybut Bożej wszechmocy.

Nędza jest poza Bogiem; jeśli jednak jest Bóg, czemu jest nędza?... Jeśli jest Bóg - to nędza poza Nim jest tym straszliwsza, dziwniejsza, niespodziewańsza, bardziej kontrastowa, głębiej i już nieskończenie wzgardzona i samotna; jeżeli nie ma Boga, to przynajmniej nędza może się pocieszać marzeniem: ach, gdybyż był Bóg; jeśli jednak On jest, a mimo to jest nędza, to już nawet i marzenie

2 K. Wyka, Karol L. Koniński, „Pamiętnik Literacki” 1946, T. 36, z. 1-2, s. 221. 
to odpada; zamknięty ostatni schron, odcięta ostatnia baza, odpada ostatnie ocalenie; wtedy jest absolutna samotność nędzy czyli piekło. Jeśli Bóg Dobry jest fikcją, czemuż są piekła, do których On nie dociera? Albo jest fikcją, albo nie chce (wtedy zaś nie jest dobry, lub dobry na jakiś zgoła inny, dla ludzkiego sumienia niepojęty i absurdalny sposób) - albo nie może?...3

Znamienne jest to, że Koniński uważał, że wrażliwość na tę sprzeczność, która powstaje, gdy wszechmoc Boga zestawiamy z obecnością zła w świecie, wzrasta w historycznej skali czasu. Pisze on, że człowiek nowożytny jest znacznie bardziej krytycznie nastawiony do zbytnio powierzchownych, gładkich wyjaśnień problemu.

To jest nasze straszliwe nowożytne chrześcijaństwo - wobec którego chrystianizm św. Teresy i św. Franciszka były jak sielanka dziecięctwa wobec wieku dojrzałego - wieku klęski. Klęskę nam przyniosło nasze rozszerzenie się wiedzy, a potem i współczuciem na całą rzeczywistość - gdy zarazem pracuje w nas bakcyl chrześcijański owej idei, że Bóg jest Miłością Doskonałą, Ojcem Miłosiernym. Nie inne, jeno chrześcijańskie sumienie dotarło do owych pytań i domagań się absolutnych, i kosmicznych. Chrześcijański bakcyl w nas fermentuje, a fermenty te obracają się przeciw chrześcijaństwu tradycjonalnemu4.

Podobnie jak Pascal wobec wszechświata, który przestał już być w jego ujmowaniu harmonią sfer niebieskich, zadał nowe, dramatyczne pytania, tak i Koniński uwzględnia postępy wiedzy o funkcjonowaniu przyrody, rozszerzenie poznawczego horyzontu. To zaś powoduje, że swoją troską obejmuje coraz szersze obszary. Litość nowożytnego człowieka osiąga wymiary takie, że sięga wręcz kosmicznych uwarunkowań istnienia. Koniński ciągle nawraca do myśli, że posiadanie sumienia jest czymś niezbywalnym w strukturze bytu ludzkiego. Co więcej, w historii sumienie jednostek coraz bardziej daje o sobie znać poprzez przyrost moralnej wrażliwości. Zwraca w szczególności uwagę na to, że wcześniejsze chrześcijaństwo traktowało przyrodę ożywioną jako coś całkowicie podporządkowanego człowiekowi.

3 K. L. Koniński, Nox atra, Warszawa 1961, s. 30.

4 Tamże, s. 35. 
Dla chrześcijan dawnych cała przyroda była tylko dodatkiem do człowieka; stworzenia jak umiały, tak chwaliły Pana Boga, ale celem ich najbliższym, racją bytu, była ostatecznie kuchnia ludzka; żaden św. Franciszek nie podniósł głosu przeciw okrucieństwom staroświeckiej kuchni; [...] do dziś dnia w świecie banalnie prawowiernym litość dla zwierzęcia uchodzi za nieprzystojną katolikowi egzaltację5.

Można tu dodać, że Koniński patrzył na problem niejako z wnętrza chrześcijańskiego świata, gdy tymczasem współczucie dla losu zwierząt w religii buddyjskiej ukształtowało się już znacznie wcześniej.

Charakterystyczne jest to, że Koniński dużo uwagi w swoim dzienniku poświęca różnym deformacjom, które tworzy przyroda, i to stanowi dla niego bardzo poważny argument podnoszony przeciwko Stwórcy.

Jeszcze romantyk w Genezis z Ducha patrzył na przyrodę jako na wzniosły warsztat, w którym się wyrabia człowiek; ale my dziś wiemy, że ewolucja życia jest rozbieżna; że są rozliczne ślepe uliczki, w których pęd życia staje, dostosowuje się do warunków mizernych i wyradza się w potwory obrzydłe. [...] oni tam wszyscy istnieją, ci nieudani, ci obarczeni haniebnymi dziedzictwami, ci psychopaci, ci niedostosowani do normy społecznej i biologicznej, ci hermafrodyci, ci z jakiegokolwiek powodu monstrualni6.

Jednak, co warto zauważyć, nie wyraża on jakiegoś zasadniczego buntu przeciwko Bogu. Mimo dostrzegania radykalnych dysonansów stara się w sposób racjonalny wyjaśnić antynomie rozsadzające Boże stworzenie. Rozum i sumienie zachowują status ciągłego probierza do oceny rzeczywistości, nie pozwalając na przyjmowanie łatwych, uspokajających rozwiązań.

Koniński, próbując zgłębić labirynty teodycei, poddaje dyskusji albo odrzuca niektóre dogmaty chrześcijaństwa. Z pewnością nie da się go zaliczyć do dogmatycznego wyznawcy katolicyzmu czy w ogóle chrześcijaństwa. Taką opinię wyraża między innymi Konrad Górski we wstępie do Ex labyrintho, a Henryk Bednarek we wprowadzeniu do Nox atra pisze o intelektualnych „zwadach” Konińskiego z Kościołem. Koniński wskazuje na trudności związane z pojęciem

5 Tamże, s. 41.

6 Tamże, s. 44, 45. 
grzechu pierworodnego i grzechu w ogóle. Jak zauważa, doskonałość i wszechmoc Boga jest nie do pogodzenia $\mathrm{z}$ istnieniem grzechu. Jeśli bowiem Stwórca stworzył Ład, to skąd wziął się nieład grzechu? Przesunięcie odpowiedzialności za sprawczość grzechu na upadłe anioły nie niweluje trudności logicznej.

Przypuszczając możliwość grzechu u istoty, która doskonale czystą wyszła z rąk Boga, obarcza się tym grzechem Boga jako twórcę grzesznego pomysłu - co jest absurdem i bluźnierstwem, sprzeczne z definicją Boga, przez sumienie podaną?.

Należy jednak zauważyć, że bez przyjęcia nauki o grzechu pierworodnym nie da się wytłumaczyć istnienia deformacji, które są obecne w przyrodzie. Choć tu istnieje trudność związana $\mathrm{z}$ faktem, że grzech ma wymiar moralny i nie widać łatwego przejścia od porządku zła moralnego nim spowodowanego do wszelkich postaci zła fizycznego w świecie przyrodniczym, do którego przecież należy i człowiek.

Koniński odrzuca też możliwość istnienia wolności niczym nie zdeterminowanej u stworzeń Bożych, bo przeczyłoby to wszechmocy Boga, jeśli byśmy wprowadzili $\mathrm{w}$ ten sposób pozaboską autokreację. Trzeba dokonać wyboru pomiędzy rzeczywistą wolnością człowieka i aniołów, a faktyczną wszechmocą Boga-Stwórcy. Dalej, zauważa myśliciel, jeśli przyjąć, że Bóg udzielił z siebie daru wybierania między dobrem i złem, to oznaczałoby, że wybiera między wartością a antywartością, a jako dobroć doskonała nie może tego czynić. Bóg może wybierać tylko to, co doskonałe, i w tym sensie nie posiada wolności wyboru. Paradoksalnie zatem i w człowieku wartościowe jest to, co nie polega na wolności wyboru, lecz na niemożliwości wyboru. „Nie żadna «wolna wola» jest naszą godnością, ale tylko i jedynie dobra a silna wola" ${ }^{8}$. Być może dylemat Boskiego wyboru, o którym pisze Koniński, da się złagodzić, jeśli przyjąć, jak Mikołaj Bierdiajew, że to sam Bóg jest wolnością, a nie w wolny sposób wybiera. Inna trudność, na którą zwraca uwagę Koniński, polega na tym, że wybór między Bogiem a Złem oznacza, przy opcji na rzecz Zła i znajomości zarówno Boga, jak i Zła, faktycznie stanie się złym bogiem. To zaś prowadzi do jawnego manicheizmu.

7 Tamże, s. 54.

8 Tamże, s. 59 
Koniński, trzeba to zauważyć, swojej refleksji teodycealnej nie prowadził za pomocą odtreściowionych pojęć. Wręcz przeciwnie. Przeplata ją licznymi przykładami z życia wziętymi, które zdają się jeszcze bardziej wzmagać jego poznawcze niepokoje. Argumentacja rozumu przechodzi często w krzyk przeżywania niezgody i bólu. Refleksja Konińskiego, który kładzie nacisk na wiodącą rolę sumienia w kontakcie człowieka z pogrążonym we złu światem, jego jakaś organiczna niezgoda na wyzierające zewsząd przykłady bólu istnienia, wiedzie go w stronę rozwiązań gnostyckich. Trudno przypisać mu nastawienie manichejskie, gdzie zasady Dobra i Zła są sobie równoważne, ale można mówić o jakimś rodzaju gnozy, której konsekwencją jest nacisk na ograniczenia Bożej wszechmocy. Wtedy można zdjąć z Boga odpowiedzialność za istnienie zła, a także przyjąć, że Bóg zmaga się ze złem, pracuje nad jego zniweczeniem. Zło, zauważmy, nie tylko w świecie statycznie jest usadowione, ale i ma tendencję do ekspansji. Dlatego potrzebna jest siła, która je zwalcza, a nie tylko od niego odgradza.

Ograniczenie mocy Boga, o którym mówi nasz myśliciel, odnosi się do niższego „piętra” Bożej rzeczywistości. Mamy więc tu zstępujący schemat właściwy rozwiązaniom gnostyckim, choć nie tak rozbudowany, jak u starożytnych gnostyków (np. Bazylides, Walentyn). Koniński wprowadza rozróżnienie na Boga-Absolut-Stwórcę i Boga-Ducha:

[...] Plan Czasu, gdzie Bóg Duch, nie wszechmocny, ale pracujący, wzdycha, cierpi, mozoli się, oburza się na zło; gdzie absolutyzm moralny; gdzie objawienie Chrystusowe historyczne i objawienie w sumieniu; gdzie wolność, wolność wyboru między Bogiem a piekłem. I plan wieczności, gdzie wszystko już gotowe, zdeterminowane, gdzie wielki relatywizm moralny, absolutny relatywizm Absolutu, inna logika niż logika, która w czasie obowiązuje?

Aby jednak nie doszło do rozpadnięcia się związku pomiędzy Bogiem Czasu i Bogiem Wieczności, czego wymaga wiara, to trzeba zdać się na nią i przyjąć, że związek ten jest niepojmowalny rozumem ludzkim. 
Tylko wiara zostaje, naga i bezwstydna wiara - komu taka właśnie wiara potrzebna. Jakiż więc stosunek Boga Ducha do boga Stwórcy? Niepojęty. Sam tylko Logos to rozumie i tylko on. W każdym razie - i to jest conditio sine qua non religijnego sumienia - Bóg absolut, stwórca nie może mieć innej woli, niż Bóg Duch. A Bóg Rozum innego rozumu niż Stwórca ${ }^{10}$.

Koniński jednak zdawał sobie sprawę, że koncepcja rozwijającego się Boga nasuwa trudności. W innym miejscu ${ }^{11}$ zauważa, że zakładałaby ona jakieś uwięzienie Go w czasie, uprzednią nieobecność. Stąd zapewne jego myśl o owej hierarchicznej strukturze w Bogu, o jakimś rozdwojeniu.

Koniński dochodzi do wniosku, że racjonalne formy teodycei są czymś szkodliwym, bo usprawiedliwiają Boga, pomniejszając zło. Dlatego należy zająć postawę pokory wobec Boga Wszechmocnego, który obok zła stworzył też sumienie wzywające do walki ze złem. Natomiast Bóg Pracujący jest tą stroną boskości, która ujawnia możliwość wyjścia z antynomii stwarzanych wskutek obecności zła w świecie. Takie pojmowanie Boga, bliskiego człowiekowi naznaczonemu przez przejawy zła, które dostrzega jego wrażliwość i to w coraz większej skali, zbliża Konińskiego do poglądu o powszechnym zbawieniu, o apokatastazie. Zarzuca on zwolennikom istnienia wiecznego piekła, że Byt utożsamiają z wartością, a niewartości piekła nadają status Bytu wiecznego. Przypisując Bogu pełnię i przyjmując nawet jakieś minimum czegoś niewartościowego w jego łonie, niszczy się wartość Boga. Nawet jeśli przyjmiemy, że piekło jest nie w Bogu, ale poza Bogiem, to i tak stworzenie przez Boga czegoś niewartościowego, czyli piekła, niszczy jego własną wartość.

Koniński odrzuca też pogląd św. Augustyna, że obraza nieskończonej wartości Boga powinna znaleźć adekwatną karę w istnieniu wiecznego piekła. To bowiem przeczyłoby nauce o Bogu, który jest Miłością. Najbliższy sposobem myślenia o piekle był dlań Orygenes:

[...] chrześcijaństwo Orygenesowe nie zna potępienia definitywnego; nie ma piekła, są tylko czyśćce, straszliwe i długie, życie na tej smutnej ziemi jest już jakimś czyśćcem; jak użyjesz tego czyśćca? I tak by się tłumaczyło cierpienie

$10 \quad$ Tamże, s. 77.

11 Tamże, s. 104. 
pozornie niewinnych ludzi (ale cierpienie dożywotnie psa na łańcuchu, zgłodniałego i sparszywiałego?...). Dla nas, ludzi nowożytnych, o duszy szeroko na świat otwartej, możliwym jest tylko chrystianizm w stylu Orygenesowym².

Fakt, że i dzisiaj nauka o apokatastazie zdobywa coraz więcej zwolenników (przykładem Wacław Hryniewicz) w łonie katolicyzmu (w prawosławiu wcześniej ją rozpowszechniano) świadczyć może o trafności prognoz Konińskiego. Z drugiej jednak strony, czy w spłyconej wersji taka nauka nie powoduje folgowania wobec różnych moralnych wynaturzeń? Nie przyjmuje jednak Koniński nauki Orygenesa bezkrytycznie. Zauważa, że nie wszystkie cierpienia uszlachetniają duchowo (na przykład cierpienia dzieci i istot nierozumnych). Tak samo nie wyjaśnia ona nieustannej walki o byt w przyrodzie. Optymizm poglądu o apokatastazie grozi też bagatelizowaniem grzechu. Orygenes, jak i wszyscy ludzie, nie jest też w stanie wskazać faktycznej genezy grzechu. Bo jeśli zło zostanie wyeliminowane, to dlaczego w ogóle zaistniało?

Nastawienie filozoficzne Konińskiego miało charakter antyscholastyczny, co sam podkreślał. Teologia Boga jako Absolutu, którego zgłębianie wprzęga racjonalistyczną logikę i cały rozbudowany aparat systematyzacji, nie odpowiada obrazowi świata, w który człowiek jest uwikłany, a nie tylko go ogląda. Dlatego optuje za procesualną koncepcją Boga-Miłości, Boga Pracującego. Znamienne jednak jest to, że nie opowiada się pozytywnie za boskością Chrystusa. Chrystus jest dla niego doskonałym Mistrzem, kimś, kto w maksymalnym stopniu przepełnił się Bożą energią. Takie podejście powoduje, że nie znajdziemy w pismach Konińskiego rozważań poświęconych zmartwychwstaniu Chrystusa i znaczeniu tego zmartwychwstania dla pokonania zła. Bóg Pracujący nie jest Bogiem Cierpiącym, składającym Ofiarę za ludzkość i świat. Sceptyczny wobec cudów i zmartwychwstania nowożytny umysł Konińskiego jakby omija temat dramatu ofiarnej męki Chrystusa, która owocuje zmartwychwstaniem i znaczenia ofiary w życiu ludzkim, bo widzi tylko bezsens cierpienia. Brak ten w refleksji Konińskiego, podobnie jak jego sceptycyzm, co do realności cudów, wynika chyba z tego, że nie jest on skłonny całkowicie rezygnować z argumentów i wątpliwości podsuwanych przez rozum. Widać u niego ciągłe zmaganie się racji serca i sumienia z racjami

12 Tenże, Nox atra, s. 139. 
rozumu. Nie jest skłonny, jak Tertulian czy Lew Szestow, przystać na prymat prawdy absurdalnej.

Świat opisywany przez Konińskiego to obszar, w którym duch ludzki konstatuje swoje uwięzienie $\mathrm{w}$ materii przyrody $\mathrm{z}$ obecnymi $\mathrm{w}$ niej wszelkimi przejawami zła, którego człowiek nie tylko doświadcza na sobie, ale i przeżywa jego doznawanie przez innych ludzi i żywe stworzenia. W tym sensie jest to Świat człowiekowi obcy, swoją obecność w nim odczytuje on jako katastrofę. Refleksje Konińskiego przypominają więc w jakimś stopniu gorzkie zapisy Emila Ciorana. W obydwu przypadkach widać przytłoczenie ogromem światowego zła. Z tym, że u Ciorana więcej jest sarkazmu i ironii. Obaj ciążą w stronę gnostyckiej wizji świata, z tym że Cioran skupia się chyba bardziej na temacie złego demiurga, zaś Koniński wspomina o jakimś pozaboskim chaosie. Koniński nie podważa faktu wiary. Poszukuje wiary i sądzi, że ją posiada. Jednak jest to wiara poddawana krytycznemu osądowi przez rozum owego „nowożytnego człowieka”, który utracił poznawczą niewinność i naiwność. Scholastyka średniowieczna, której zwolennikiem nie był, potrafiła godzić wymogi rozumu z dogmatami wiary chrześcijańskiej. Był to jednak rozum w znacznej mierze spekulatywny. Tymczasem Koniński pisał już w epoce, gdy wiedza przyrodnicza sięgnęła w dalekie rejony, ukazując bardzo złożony obraz świata. To powoduje inne spojrzenie na dogmatykę i źródła religijnej nadziei.

Widać to choćby na przykładzie jego oceny Orygenesa, do którego przecież w pozytywny sposób nawiązywał:

Lecz Orygenes pląta się; pląta się w swojej apologetyce; biedne są i przykre chytre wybiegi tego prawego człowieka, kiedy usiłuje usprawiedliwić i oczyścić, zhumanizować Boga prymitywnego Ksiąg Mojżeszowych, boga rzezi, mordów, okrucieństw, oszustwa i łupiestwa; daremne wysiłki! [...] Ja, człowiek nowożytny, odrywam się od niewoli Pisma; zrywam tabu Kanonu - i już jestem heretykiem; ale jestem prawowierny wobec jednego i jedynego Objawienia, które mi się narzuca, z całą mocą rzeczy rzeczywistych od dwóch stron: od wewnątrz, od sumienia, w którym słyszę podszepty Miłości; a to są wszystkie podszepty szlachetne; przemyślawszy, co jest, znajduję logikę miłości, jako logikę daną mi obiektywnie, wedle której sadzę wszystko, co się tyczy świata i Boga. Od zewnątrz, znajduję Objawienie we fakcie historycznym świętości, która afirmowa- 
na jest przez moje sumienie, moją synderesis, i która, ze swej strony, rozwija mi sumienie, swoim wzorem idealnym przykuwa sumienie do siebie, ukazuje mi we wspaniałej pełni realizowaną tę logikę obiektywną Miłości, której ja, człowiek zwykły, zaledwie ku dobremu skłonny, mam w sobie ledwo nikłe zarysy. Na tych faktach oparty, obchodzę się bez Kanonu Pisma ${ }^{13}$.

Krytycy zarzucali Konińskiemu dryfowanie w stronę herezji, ze względu na wybiórcze traktowanie dogmatyki katolickiej. Jak choćby ze względu na bardzo minimalistyczną chrystologię czy odrzucanie dogmatu o Trójcy Świętej, Bożej wszechmocy albo piekle. Teodycea, którą w swoich zapiskach pracowicie i w bólu wykuwał, wyrasta z pewnej formy katolickiego modernizmu, który był mu chyba bliski. Trudno nazwać go fideistą, gdyż pisze o Bogu jako bycie osobowym. Bliskie były mu idee Wiliama Jamesa i Stanisława Brzozowskiego, które niewątpliwie miały swój wpływ na jego koncepcję pracującego Boga. Koniński zagadnienia teodycei traktował jako centralne dla wiary chrześcijańskiej. Zastanawiając się nad światowym złem i przeżywając je, oddzielał, w zakresie prób wyjaśnienia jego genezy, ziarno od plew. Obca była mu usypiająca moc dogmatów, które konfrontował z codzienną, także wojenną rzeczywistością. Koniński przeniósł metafizykę, która często kostnieje w abstrakcyjnych formułach, w obszar podstawowych doświadczeń ludzkiego cierpienia, poszukując namiętnie drogi wyjścia z labiryntu zagadek, które pojawiają się, gdy człowiek próbuje swoim ograniczonym poznaniem przeniknąć je. Wskazuje też, w jakim trudzie może rodzić się w człowieku religijna wiara. Jego głos stanowi istotny wkład do polskiej myśli filozoficznej i teologicznej, ponieważ nie wahał się iść poza utartymi traktami.

\section{Bibliografia}

Koniński K. L., Ex labyrintho, Warszawa 1962.

Koniński K. L., Nox atra, Warszawa 1961.

Ludwicki K., Bóg-zło-modlitwa. Wokół „Uwag 1940-1942” Karola Ludwika Konińskiego, Kraków 2016.

Mamoń B., Karol Ludwik Koniński, Kraków 1969.

Wyka K., Karol L. Koniński, „Pamiętnik Literacki” 1946, T. 36, z. 1-2, s. 205-224.

13 Tamże, s. 209-210. 